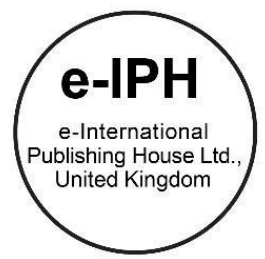

\title{
Human Behaviour and Responses Challenge towards Emergence of Infectious Diseases: E.coli clinical isolate
}

\author{
Ummi Mohlisi Mohd Asmawia Mohammad Nazmul Hasan Maziza, \\ Mohammad Abdur Rashida, Jamal Houssainia \\ aFaculty of Medicine, \\ Universiti Teknologi MARA, 47000 Sg.Buloh, Selangor, Malaysia
}

\begin{abstract}
Consumption of undercooked ground beef is the most common route of transmission of verotoxin-producing E.coli. It is estimated that non0157 verotoxigenic E.coli (VTEC) can cause diarrhea.The sample was isolated from Universiti Malaya Medical Centre. All the isolates were identified using agarose gel electrophoresis method. This study aims to detect the verotoxin genes and detect the link or involvement of plasmids with these verotoxin genes. Therefore, this study will contribute to shed new light on resolving the significant and global problem of diarrheal disease caused by this particular pathogenic organism and help in improvising novel therapeutic approaches to improve human healthcare.

eISSN: 2398-4287@ 2016. The Authors. Published for AMER ABRA by e-International Publishing House, Ltd., UK. This is an open access article under the CC BY-NC-ND license (http://creativecommons.org/licenses/by-nc-nd/4.0/). Peer-review under responsibility of AMER (Association of Malaysian EnvironmentBehaviour Researchers), ABRA (Association of Behavioural Researchers on Asians) and CE-Bs (Centre for Environment-Behaviour Studies), Faculty of Architecture, Planning \& Surveying, Universiti Teknologi MARA, Malaysia.
\end{abstract}

https://doi.org/10.21834/e-bpj.v1i1.208

Keywords: E.coli; non-0157; plasmid profile

\section{Introduction}

Non-0157 E. coli is commonly present in environment, food and food production animals. Problems associated with these emerging pathogens are increasing day by day (Bettelheim, 2000). Previously attention has been focused on infections caused by isolates of $\mathrm{E}$. coli 0157 serotypes. Infections with non-0157 E. coli are now increasingly recognized in many countries (Schmidt et al., 1999). Many non-0157:H7 isolates that are associated with outbreaks do not possess either eae or the p0157 plasmid (Bokete et al., 1993) indicating that there must be additional, as yet unknown, virulence factors that distinguish pathogenic from non-pathogenic non-0157 E. coli strains. The virulence profiles of most non-0157 E. coli are unknown (Schmidt et al., 1999). Therefore, characterization of non-0157 VTEC isolates is necessary for improving our knowledge of these organisms (Nielsen \& Andersen, 2003).

\footnotetext{
${ }^{*}$ Corresponding author. Tel.: +6-013-389-8340; fax: +6-03-6126-5224.

E-mail address: umieasmawi@ salam.uitm.edu.my.
}

eISSN: 2398-4287@ 2016. The Authors. Published for AMER ABRA by e-International Publishing House, Ltd., UK. This is an open access article under the CC BY-NC-ND license (http://creativecommons.org/licenses/by-nc-nd/4.0/). Peer-review under responsibility of AMER (Association of Malaysian EnvironmentBehaviour Researchers), ABRA (Association of Behavioural Researchers on Asians) and cE-Bs (Centre for Environment-Behaviour Studies), Faculty of Architecture, Planning \& Surveying, Universiti Teknologi MARA, Malaysia. 
Plasmid is a small, covalently closed circular, double stranded extra chromosomal deoxyribonucleic acid (DNA) element. It is self-replicating independent DNA molecule. The plasmid contains the gene that is normally not essential for bacterial survival or growth. Plasmid commonly carries one or more genes that can confer the advantage to the bacterial cell harboring them. Plasmid may confer toxin production, drug resistance, etc. Plasmid profiling analysis sometime can be used for epidemiological analysis (Bratoeva et al., 1992). The size of the plasmid may vary from $1 \mathrm{~kb}$ to $250 \mathrm{~kb}$. Different size of plasmids may be found in a single host bacterium, and not all bacteria may contain the plasmid. In the same bacterial cell, many copies of a single plasmid can be found which can be extracted in the laboratory using different methods. Many plasmid DNA extraction methods have been established to date. The presence of plasmids confers antibiotic resistance that plays a role in human behavior when they are under any antibiotic therapy.

\section{Literature Review}

In July 2015, the U.S. Department of Agriculture's Food Safety and Inspection Service (FSIS) has announced and recalled approximately 26,975 pounds of tenderized steak and ground beef products issued by Denver's Lombardi Brothers Meats that may be contaminated with E. coli 0157:H7. No illnesses are yet known to be associated with the meat, which was distributed to hotels, restaurants and institutional use customers in Colorado, New Mexico, Utah and Wyoming. This problem was discovered by Lombardi Brothers when the company's sampling program returned a positive $E$. coli test result. It then found that some products made from the same source were shipped into commerce (FSIS, 2015).

E. coli $0157: H 7$ is a potentially deadly bacterium that can cause dehydration, bloody diarrhea and abdominal cramps 2-8 days (3-4 days on average) after exposure to the organism. While most people recover, some develop a type of kidney failure called hemolytic uremic syndrome (HUS). The condition can occur among persons of any age, but is most common in children younger than five and older adults. It is marked by easy bruising, pallor and decreased urine output. Persons who experience these symptoms should seek emergency medical care immediately (FSIS, 2015).

FSIS routinely conducts recall effectiveness checks to verify recalling firms notify their customers of the recall and that steps are taken to make certain that the product is no longer available to consumers. United State Department and Agriculture (USDA) advises all consumers to safely prepare their raw meat products, including fresh and frozen, and only consume beef products that have been cooked to a temperature of 145 degrees $F$ for steaks and roasts and 160 degrees $F$ for ground product (FSIS, 2015).

Non-0157 verotoxigenic E. coli (VTEC) are common typical E. coli and are commonly present in food and food production animals. Transmission is produced by consumption of contaminated food, by direct contact with animals or the environment and from person to person (Polifroni et al., 2014). However, consumption of raw/undercooked ground beef is the most common route of transmission of verotoxin-producing E. coli (Liorente et al., 2014). E. coli serotypes now known to be VTEC were present in humans and animals many years ago but have acquired the ability to produce VT and probably other virulence factors (Bettelheim, 2000). E. coli serogroups 026, 045, 0103, 0111, 0121, and 0145 are the leading cause of VTEC-associated infections in humans (Liao et al., 2014). Multidrug resistances in non 0157 E. coli were also observed (Rajkhowa \& Sarma, 2014). Research on the E. coli non-0157 serogroups is limited. In recent years increased attention has been focused on infections caused by non-0157 E. coli isolates as infections with non-0157 VTEC are now increasingly recognised in many countries (Ma et. al., 2014). It is estimated that non-0157 VTEC may cause diarrhoea at frequencies similar to those of other enteric bacterial pathogens, such as Salmonella and Shigella. The virulence mechanisms of most non-0157 E. coli are unknown (Schmidt et al., 1999, Joseph \& Mohammad, 2012). Therefore, characterization of non-O157 VTEC isolates are essential for improving our knowledge about the virulence mechanism of these organisms (Misselwitz et al., 2003). To date, VTEC prevalence studies have focused primarily on $\mathrm{E}$. coli 0157 : $\mathrm{H}$, because of its initial predominance in human clinical infection. Culture and molecular methods for the detection of VTEC have thus been developed and optimized for that serotype, with little attention to and resultant underestimation of the risks posed by non-0157 serogroups. However, non-0157 infections are of primary concern in several countries (Áine et al., 2011). VTEC produces two types of Verotoxin, VT1 and VT2. Both the antigenically distinct toxins VT1 and VT2 are encoded on two different lysogenic lambdoid bacteriophages (933J and 933W) inserted into the chromosome in 0157 E. coli 933 (Nataro \& Kaper, 1998). The T1-like bacteriophages were shown to lyse common phage types of verotoxin- producing Escherichia coli 0157: H7 (VTEC 0157: H7), but not non-0157 E. coli (Niu et al., 2014). 
Our previous study (unpublished) suggests that the VT gene might be present in the plasmid, but the mechanism of its presence in the plasmid was not understood yet. How these verotoxin genes are transmitted to these bacteria? Is there any correlation between plasmid and verotoxin gene? Can verotoxin gene be located in the plasmid? In the light of this, we are prompted to study further. We are not aware of any studies of these verotoxin genes to be plasmid mediated. To the best of our knowledge, not enough studies have been carried out about the association of plasmids in verotoxin production. This prompted us to carry out this study that will help advance our knowledge about the implication of plasmid in verotoxin production among the clinical isolates of VTEC. On completion, this study aims to detect the verotoxin genes and detect the link or involvement of plasmids with these verotoxin genes. Therefore, we hope that from the findings, it can shed new light on resolving the significant and global problem of diarrheal disease caused by this particular pathogenic organism and help in improvising novel therapeutic approaches. Knowledge of plasmid related verotoxin genes will help in formulating novel therapeutic approaches.

\section{Methodology}

Sixty non-0157 E. coli clinical isolates were used in this study. These were obtained from Universiti Malaya Medical Centre, Kuala Lumpur. Supercoil DNA was used to provide reference plasmids of known molecular weight that was purchased from Promega, USA.

Perfectprep Plasmid Mini preparation kit from Eppendorf, Germany, was used to extract Plasmid DNA. The exact procedure was followed according to manufacturer's instructions, and no further modification was done. This isolation technique gave plasmid DNA bands in patterns, and this technique was found to be stable, i.e., reproducible recovery of all plasmid DNA was observed from all the $\mathrm{E}$. coli isolates. Firstly, the plasmids of all the $60 \mathrm{E}$. coli isolates were extracted. The experiment was repeated few times for the confirmation of the findings. After purification, the plasmids were analyzed to estimate the approximate size by using the graphical method of Aiij and Borst (1972).

\section{Agarose gel electrophoresis}

Plasmid DNA was resolved by electrophoresis in submerged horizontal agarose slab gel $(0.7 \%)$ in Tris-Acetate buffer (TAE) (pH 8.3). The agarose (Sigma Chemical Co., USA) was dissolved by boiling in $1 \mathrm{X}$ Tris-Acetate (TAE) buffer (pH 8.3) followed by cooling at $500 \mathrm{C}$. Ethidium bromide $(0.5 \mu \mathrm{g} / \mathrm{ml})$ was added before casting. A $25 \mu \mathrm{l}$ aliquot of extracted plasmid DNA was mixed with 5-10 $\mathrm{l}$ gel loading buffer. The DNA-dye mixture was then loaded into the well. The tank was filled with $1 \mathrm{X}$ Tris-Acetate (TAE) buffer ( $\mathrm{pH}$ 8.3) to completely submerge the gel. Electrophoresis was supplied by a power pack (Model Vokam 400, Shandon Co. Ltd, England). Electrophoresis was carried out from the cathode (-) to anode (+) at a constant voltage at room temperature. The voltage used was in the range of $70-90$. Electrophoresis was stopped when the tracking dye (loading buffer) was $5-10 \mathrm{~mm}$ from the anode end of the gel. The DNA-ethidium bromide complex was visualised using UV transilluminator (Model TFX, Vilber Lourmat, France). Gloves were worn at all times when handling agarose slab gels containing ethidium bromide. Photography was carried out with a Polaroid camera and Polaroid 665 black and white film. Exposure time was between 30-90 seconds. Digital camera was also used for photography and downloaded the image directly to the computer. The brightness and contrast of the image were adjusted before printing.

\section{Findings}

Plasmids were detected in 42 isolates with the Plasmid Occurrence Rate (POR) of 70\%. These 42 isolates appear to harbor 1 or more plasmids with the maximum of 4 plasmids. Eighteen E. coli isolates $(30 \%)$ did not carry any plasmids. The overall sizes of the plasmid DNA range from the lowest $1.6 \mathrm{~kb}$ to the highest $7.2 \mathrm{~kb}$. (Figure 1)

The plasmid profile analysis revealed the presence of a 7.2-kb plasmid DNA harbored by 5 non-0157 E. coli isolates. This result is in agreement with Wan Himratul (1999) findings where different strains were used. This 7.2-kb plasmid from non-0157 was previously shown to be associated with VT1 production. DNA hybridization studies showed that, this $7.2 \mathrm{~kb}$ plasmid to be hybridized against VT1 probe (Wan Himratul, 1999).

Five of the E. coli isolates harbored a $6.6 \mathrm{~kb}$ plasmid. This size plasmid was also reported by Wan Himratul, (1999), and a plasmid of similar size was also reported by Scaletsky et al., (1995). Scaletsky et al., (1995) reported the $6.6 \mathrm{~kb}$ plasmid to be very significant in its pathogenesis. Bacteria containing this plasmid synthesize a protein of $32 \mathrm{kDa}(\mathrm{pl} 4.93)$ which seemed to be required for cell invasion. They isolated this $6.6 \mathrm{~kb}$ plasmid from an 0111: $\mathrm{H}$ - EPEC that is capable of conferring to an avirulent, non-adherent E. coli k12 strain (DK1) the capacity to invade epithelial cells. Similar studies are required to observe the pathogenesis of the $6.6 \mathrm{~kb}$ plasmid harbored by the E. coli isolates in this study. 


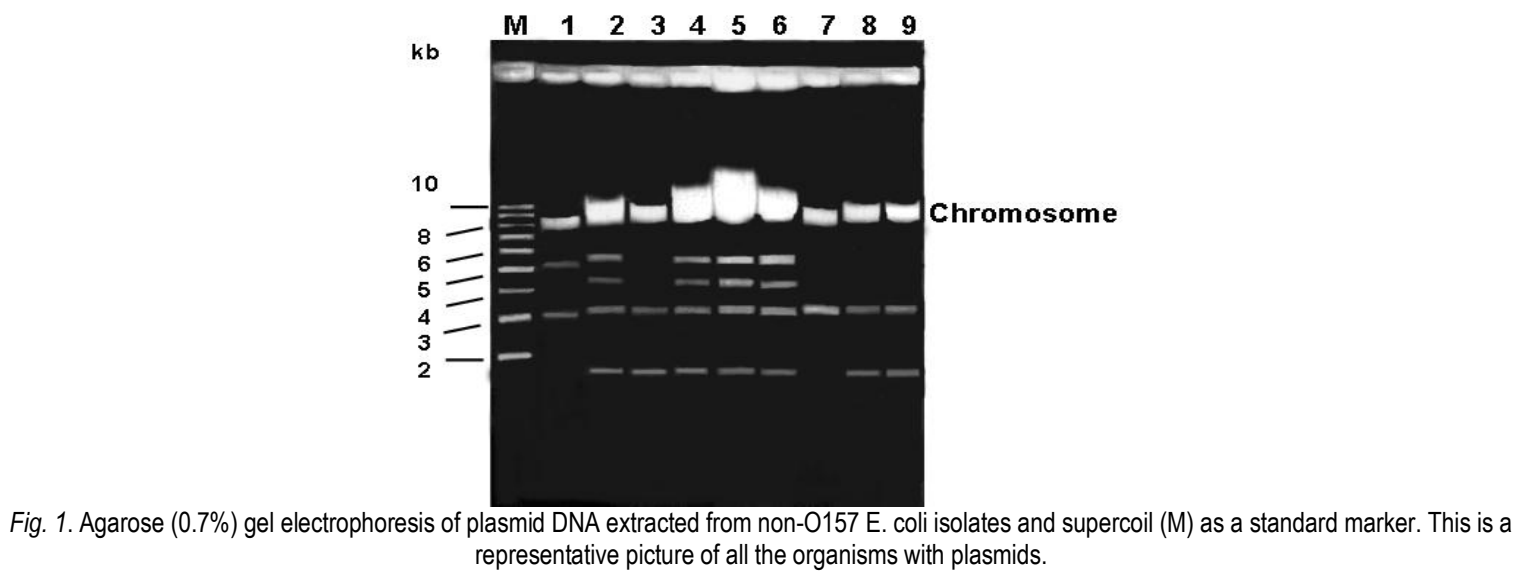

The most common plasmid found was a $4 \mathrm{~kb}$ plasmid, which was harbored by $14 \mathrm{E}$. coli isolates. Wan Himratul, (1999) also showed a similar finding in Malaysia when tested different isolates, where 16 diarrheagenic $\mathrm{E}$. coli were found to harbor a 4.6-kb plasmid. Another common plasmid found was $5 \mathrm{~kb}$ plasmid. The significance of these plasmids is yet to be known. Gyles et al. (1974) found plasmids coding for heat stable enterotoxins was in the range of 3.2-12 kb. It suggests that any of this plasmid might be involved in producing heat stable enterotoxin but requires further study to confirm its association with the toxin production.

Eight E. coli isolates harbored two plasmids of $3.2 \mathrm{~kb}$ and $1.6 \mathrm{~kb}$. One possible explanation for this $3.2 \mathrm{~kb}$ plasmid, is that may be a dimer of $1.6 \mathrm{~kb}$ plasmid, in which there is only one plasmid DNA that is present in two possible forms namely super helical of covalently closed circular (CCC) and relaxed form or open circular (OC). Two E. coli isolates were found to harbor only $3.2 \mathrm{~kb}$ plasmid without harboring $1.6 \mathrm{~kb}$. Wan Himratul (1999) also showed that these two plasmids were harbored by two different $\mathrm{E}$. coli isolates. These findings indicate that these two $3.2 \mathrm{~kb}$ and $1.6 \mathrm{~kb}$ plasmids may be of different origin and unrelated, not a dimer. But the significance of these two plasmids is yet to be reported.

Four E. coli isolates were observed to have identical plasmid profiles carrying four different size plasmids of $5,4,3.2$ and $1.6 \mathrm{~kb}$. Another $4 \mathrm{E}$. coli isolates also showed to harbor identical plasmid profiles carrying 3 different size plasmids of $7.2,6.6$ and $5 \mathrm{~kb}$. Many other isolates also showed identical plasmid profile among them. Identical plasmid profiles have been reported when the isolates are in same serogroups (Fernandes et al., 1992). Fernandes et al., (1992) reported the usefulness of plasmid profile analysis to differentiate strains of E. coli. They showed no common plasmid profiles among strains of distinct serotypes. However, they grouped most of the strains within a few major profiles. They also reported that plasmid profile analysis is very useful to differentiate strains within specific E. coli serotypes. All the E. coli isolates in this study need to be further serotyped to provide a finer plasmid profiling analysis as to differentiate the strains within the specific serotype. This will also lead to a better understanding of the plasmid profiles among the respective serotypes. There are several common small plasmids of similar sizes among many of the $\mathrm{E}$. coli isolates, but the significance of these plasmids is yet to be determined.

No plasmid bands were detected in $18(30 \%)$ of the E. coli isolates. This finding also agrees with the findings of Wan Himratul (1999) where $22 \%$ different strains of non-0157 E. coli isolates were shown to be plasmidless. Plasmid occurrence rate is normally significant for the epidemiological studies where a large number of isolates is tested. Plasmids are known to be associated with different virulence property of the bacterial isolates. In this study, POR is significant for the basis of further studies and each plasmid needs to be characterized to detect their role in pathogenesis (if any).

\section{Conclusion}

POR in this study was found to be $70 \%$. POR is usually more significant for epidemiological studies where a large number of isolates are tested. The presence of plasmid indicates more antibiotic resistance that can influence the human behaviour during their treatment. This study will contribute to shed new light on resolving the significant and global problem of diarrheal disease caused by this particular pathogenic organism and help in improvising novel therapeutic approaches to improve human healthcare. 
Further studies are required to confirm the contribution of plasmid in producing verotoxin. A Large number of isolates is also needed to be tested to use this POR as an epidemiological tool for non-0157 E. coli isolates. The further studies will improve the knowledge of plasmids in relation to verotoxin production and also to use plasmids as epidemiological tool.

\section{Acknowledgement}

This research was funded by the Ministry of Higher Education, Malaysia through Universiti Teknologi MARA under RAGS grant: RMI File no: 600-RMI/RAGS 5/3 (50/2014) and Sponsorship File no: RAGS/1/2014/SKK04/UITM//3.

\section{References}

Aiij, C. \& Borst, P. (1972). The gel electrophoresis of DNA. Biochimica et Biophysica Acta. 269: 197-200.

Áine M., Brian B., Séamus F., Torres S., David M. \& Declan J.B. (2011). Serotypes and Virulence Profiles of Non-0157 Shiga Toxin-Producing Escherichia coli Isolates from Bovine Farms. Applied and Environmental Microbiology 77(24): 8662-8668.

Bettelheim, K.A. (2000). Role of non-0157 VTEC. Journal ofApplied Microbiology Symposium Supplement 29(38); 38S-50S.

Bokete, T.N., O'Callahan, C.M., Clausen, C.R., Tang, N.M., Tran, N., Moseley, S.L., Fitsche, T.R. \& Tarr, P.I. (1993). Shiga-like toxin-producing Escherichia coli in Seattle children: a prospective study. Gastroenterology 105: 1724-1731.

Bratoeva, M.P., John, J.F. \& Barg, N.L. (1992). Molecular epidemiology of trimethoprim-resistant Shigella boydii serotype 2 strains from Bulgaria. Journal of Clinical Microbiology 30: 1428-1431.

Fernandes, R.M., Ramos, S.R. Rassi, V., Blake, P.A. \& Gomes, T.A. (1992). Use of plasmid profiles to differentiate strains within specific serotypes of classical enteropathogenic Escherichia coli. Brazilian Journal of Medical and Biology Research 25(7): 667-672.

Food Safety Inspection Services. 2015. Assessed online at http://www.fsis.usda.gov/wps/wcm/connect/FSIS-Content/internet/main/topics/recalls-and-publichealth-alerts/recall-case-archive/archive/2015/recall-097-2015-release

Joseph M.B. \& Mohammad, K. (2012). Predicting the Presence of Non-0157 Shiga Toxin- Producing Escherichia coli in Ground Beef by Using Molecular Tests for Shiga Toxins, Intimin, and O Serogroups. Applied and Environmental Microbiology 78(19): 7152-7155.

Liao, Y.T., Miller, M.F., Loneragan, G.H., Brooks, J.C., Echeverry, A. \& Brashears, M.M. (2014). Non-0157 Shiga toxin-producing Escherichia coli in U. S. retail ground beef. Journal of Food Protection 77(7):1188-92.

Liorente, P., Barnech, L., Irino, K., Rumi, M.V. \& Bentancor, A. (2014). Characterization of Shiga toxin-producing Escherichia coli isolated from ground beef collected in different socioeconomic strata markets in Buenos Aires, Argentina. BioMed Research International 2014(795104): 1-9

Ma, J., Mark Ibekwe, A., Crowley, D.E. \& Yang, C.H. (2014). Persistence of Escherichia coli 0157 and non-0157 strains in agricultural soils. Science of The Total Environment 490:822-829

Misselwitz, J., Karch, H., Bielazewska, M., John, U., Ringelmann, F., Ronnefarth, G. \& Patzer, L. (2003). Cluster of hemolytic-uremic syndrome caused by Shiga toxin-producing Escherichia coli O26:H11. The Pediatric Infectious Disease Journal 22(4): 349-354.

Nataro, J.P. \& Kaper, J.B (1998). Diarrheagenic Escherichia coli. Clinical Microbiology Reviews 11:142-201.

Nielsen, E.M. \& Andersen, M.T. (2003). Detection and characterization of verocytotoxin-producing Escherichia coli by automated 5' nuclease PCR assay. Journal of Clinical Microbiology 41(7): 2884-2893.

Niu, Y.D., McAllister, T.A., Nash, J.H., Kropinski, A.M. \& Stanford, K. (2014). Four Escherichia coli 0157:H7 phages: a new bacteriophage genus and taxonomic classification of T1-like phages. PLoS One. 9(6):e100426. 1-11

Polifroni, R., Etcheverría, A.I., Arroyo, G.H. \& Padola, N.L. (2014). Survival of VTEC 0157 and non-0157 in water troughs and bovine feces. Revista Argentina de Microbiologia 46(2):126-132.

Rajkhowa, S. \& Sarma, D.K. (2014). Prevalence and antimicrobial resistance of porcine 0157 and non-0157 Shiga toxin-producing Escherichia colifrom India. Tropical Animal Health Production 46(6):931-937.

Schmidt, H., Geitz, C., Tarr, P.I., Frosch, M. \& Karch, H. (1999). Non-0157:H7 pathogenic Shiga toxin-producing Escherichia coli: phenotypic and genetic profiling of virulence traits and evidence for clonality. Journal of Infectious Diseases 179(1): 115-123.

Wan Himratul, A. (1999). Detection and molecular analysis of non-0157 diarrheagenic Escherichia coli isolates by using VT1 probe. (Master's thesis, University of Malaya, Malaysia). 